\title{
Urgences
}

\section{Dernière audace}

\section{Lise Potvin}

Numéro 15, octobre 1986

Épigraphiques

URI : https://id.erudit.org/iderudit/025288ar

DOI : https://doi.org/10.7202/025288ar

Aller au sommaire du numéro

Éditeur(s)

Urgences

\section{ISSN}

0226-9554 (imprimé)

1927-3924 (numérique)

Découvrir la revue

Citer ce document

Potvin, L. (1986). Dernière audace. Urgences, (15), 20-20.

https://doi.org/10.7202/025288ar

Ce document est protégé par la loi sur le droit d'auteur. L’utilisation des services d'Érudit (y compris la reproduction) est assujettie à sa politique d'utilisation que vous pouvez consulter en ligne.

https://apropos.erudit.org/fr/usagers/politique-dutilisation/
Cet article est diffusé et préservé par Érudit.

Érudit est un consortium interuniversitaire sans but lucratif composé de l’Université de Montréal, l'Université Laval et l'Université du Québec à Montréal. Il a pour mission la promotion et la valorisation de la recherche. https://www.erudit.org/fr/ 


\title{
Lise Potvin \\ DERNIËRE AUDACE
}

\begin{abstract}
Et s'il est vrai qu'il fit incendier Rome par goût pour l'Iliade, y eut-il jamais hommage plus "sensible" à une oeuvre d'art? C'est en tout cas le seul exemple de critique littéraire "en marche", d'un jugement esthétique "actif".

L'effet qu'un livre exerce sur nous n'est réel que si nous ressentons l'envie d'en imiter l'intrigue, de tuer si le héros y tue, d'être jaloux s'il y est jaloux, d'être malade ou mourant s'il y souffre ou s'il y meurt.
\end{abstract}

E.M. Cioran: Précis de décomposition

S'il est juste que Lucius Domitius Tiberius Claudius Nero s'est écrié "Chanceux roi de Troie, qui a senti la décadence de ta nation", convenons qu'il a atteint à la grandeur de la provocation, à la substance ultime de l'action esthétique et de la grandiloquence funèbre. Après une pareille sentence, si merveilleusement adaptée à la langue d'un chef d'empire, seule nous reste la platitude, on y est même astreint. Qui aurait encore le pouvoir de soutenir une excentricité? Les petits malheurs de notre banalité nous obligent à l'extase devant ce dictateur cabot et dénaturé (et cela d'autant mieux que sa folie s'est vue parée d'une auréole plus vive que les plaintes de ses martyrs, les biographies demeurant pour le moins aussi terribles que les désastres qui les provoquent). Toutes les conduites à côté des siennes semblent grimaces.

Mais tout cela, pour nous contemporains, relève de l'improbable quand ce n'est pas de l'inutile; à lui seul, le fils adoptif de Claude, il aura été donné de percevoir l'oeuvre littéraire comme un feu d'artifice; sa réplique contenait les restes de ses sujets et de son empire...

Ces paroles et ces gestes devaient, une fois au moins, être prononcés et exécutés. Un infâme les endossa. Cela peut nous apaiser, cela le doit même, sinon comment retrouverions-nous notre routine journalière et nos certitudes convenables et mesurées.

Ce n'est déjà plus de Lucius Domitius Tiberius Claudius Nero qu'il est question mais de celui qui sut, dans une ultime hardiesse, lui rendre hommage et reconnaître un sens à la scélératesse. Peut-être se trouvera-t-il un jour quelqu'un pour comprendre et justifier la nôtre... 